\title{
The Influence of Financialization on Industrial Development: An Empirical Analysis in China ${ }^{1}$
}

\author{
Xiaoyu Chen \\ School of Economics, Central University of Finance and Economics (CUFE), \\ 39 South College Road, Beijing, 100081, P.R.China
}

\begin{abstract}
The effect of China's financialization on industrial development is examined in this paper. To make the research more specifically, industrial development has been divided into three parts, namely industrial rationalization, upgrading and stabilization. Using data from 1978 to 2012, the influence of financialization on industrial rationalization, upgrading and stabilization is examined, with the empirical methods of Cointegration test, Granger Causality test and Impulse Response analysis. Although evidences from developed countries show that the development of finance can promote industrial development in many ways, the results in this paper indicate that China's financialization suppresses industrial stabilization, which can be explained by the low level of financialization accompanied with a lack of supervision. However, we still find the positive effects from financialization to industrial structure upgrading and rationalization. These empirical results are consistent with theoretical analysis developed by post Keynesian economics. The results concluded from this paper also have implications to other developing countries.
\end{abstract}

Keywords: Financialization; Industrial development; impulse response; Granger causality

\section{INTRODUCTION}

The phenomenon of financialization appeared in the U.S. in the 1980s, and spread to other economics in the last few decades. As to the definition, financialization represents both the growing size and importance of the financial sector, especially the growing income derived from financial sources as opposed to non-financial savings. Financialization resulted from a change in the gap between the rate of return on manufacturing investments as well as the rate of return on investments with financial assets. On the side of returns in finance, real interest rates got a boost in the late 1970s with tight monetary policy and the deregulation of financial markets. On the side of manufacturing, the emergence of Japan as a major U.S. competitor beginning in the late 1970s cut profits directly, especially in automobiles and electronics, lowering the return on manufacturing investments. With the returns rising in finance and slowing down in manufacturing, the incentives switch from industry to finance in the 1980s. At the same time, the "New Economy business model" (NEBS) took the place of the "Old Economy business model" in the US.

Since the 1990s, China has stepped into the World economic system. Developed countries have influenced China's industrial development from three aspects: industrial structure, market

1 The research was supported by Graduate Students' Innovation Foundation from School of Economics, Central University of Finance and Economics (CUFE). 
structure and trading product structure [1].China's financial market opened the gate gradually for foreign investment while allowing domestic residents and corporations to invest in foreign financial markets at the same time [2]. Financialization, which mainly occurred in capitalist countries, will influence China's economic development in many ways as a result. In the trend of globalization, China is supposed to adjust its economic and industrial structure to the world economy, which mainly is influenced by financialization.

A growing body of evidence indicates that the development of the world financialization had influence on China's industrial development in many ways. Foster asserted that financial capital strengthened the control from developed economies to developing economics in the Marxist view [3]. He also argued financialization was the main cause of the financial crisis in 2008. Milberg narrowed the research, and found that the U.S. financialization was the essential driver to China's current changes in the global value chain [4]. Yumin Zhao and Juzheng Yang furthered this topic from a macro view $[5,6]$. These studies pointed out some major paths from the U.S. financialization to China's industrial development, namely: (1) the degree of foreign trade dependence; (2) the financing environment; (3) resources allocation; (4) China's financial market (which can be called the domestic path).

Among these paths, the domestic path represents both financial market and innovation development in China, which is significant to economic growth. Financialization will affect industrial development in the aspect of rationalization, upgrading and stabilization. Therefore, while most of the financialization studies focus predominantly on North America and Western Europe, the scope within this paper is on China's financialization and its effects on industrial development.

The remainder of the paper is organized as follows: section 2 discusses the existing literature on the relationship of financialization and industrial structure; section 3 illustrates the econometric methodology, model specification and description of data used for testing the objective. Empirical findings are discussed in section 4, while concluding remarks are given in section 5 .

\section{LITERATURE REVIEW}

Representative views concerning the impact of financialization on the industrial development can be divided into two opposite camps. On one hand, financialization is a key driver for new economy, which produces technology innovation and consistent prosperity in the U.S. This point of view confirms the essence of financialization, as the current changes in Capitalism brought rapid profit accumulation for developed countries.

On the other hand, financialization is suggested to work against industrialization, which is supported by empirical data. On one hand, financial innovation and derivatives shaped a high payback profit model. On the other hand, manufacture is featured by long-period payback. The differences gradually expanded profits between financial and manufacture investment. As a result, financial derivatives, instead of industrial products, absorbing an increasing amount of capital, leading to the unlimited expansion in the virtual economic sector while reinforcing the movement of capital away from the real economy and thus contributing to the deindustrialization of the American economy. Unemployment rates and income distribution between different sectors are deteriorated by financialization, undermining economic stability, and in turn reducing innovation ability in high-tech industries, hampering industrial development as well. 


\section{Financialization Prompts Industrial Development}

The pro-financialization scholars examined financialization as a new regime of accumulation. Arrighi and Krippner complement research by Marxist and post-Keynesian economists, not only do they confirm that non-financial firms increasingly derive profits from financial activities, they also suggest that non-financial firms have increased payments to the financial sector through interest payments, dividends payments and share-buy-backs as well [7]. This foundation was developed by Costas Lapavitsas and Panitch to support the positive effects of financialization on industrial development, which can be corroborated by two approaches [8, 9].

A first approach focused on the financial and real economic structural changes caused by financializtion. Marxist political economy linked financialization to economic slump, which was contradicted by Costas Lapavitsas [9], who held the idea that financialization is a symbol of systematic transformation inside the capitalist economy, with corresponding changes among corporations, banks and residence behavior. Specifically, corporations develop financing services instead of relying on financial institutions; banks, faced with challenges of share decreasing, develop new services in the area of individual financial market; meanwhile, residential financing consumption increased, expanding market for individual financial services. Drawing on LinYang and Jin $\mathrm{Fu}$ etc. [10, 11], Chinese scholars explain how financialization increases industrial and financial structure upgrading. By emphasizing the inherent strong connection between financial structure and industrial structure, China's financialization scholars present the supporting mechanism paths in the view of capital liquidity.

A second approach involves scholarship that examines financialization as a new regime of accumulation. Marx has pointed out how the transformation from industrial capital to financial capital is a dominant trend when virtual economy developed. However, while most of the literature focuses on the negative effects of excess liquidity caused by financialization, Panitch and Gindin argue that financialzation actually helps accumulation by imposing the closure of unprofitable businesses and by encouraging mergers and acquisitions, which expands capital's ability to exist [8]. They are against the view that financialization crowds out investment in real sector, because the growing profits offer more capital for reinvestment. Financialization strengthens the liquidity of venture capital, promoting high-technology diffusion among different sectors, attracting capital from low profit sectors to high profit sectors. Therefore, making use of financial profits to upgrade technology and enlarge market share is more acceptable than de-financialization. Fang Wang and Feng Chen examined promotion mechanism empirically with Chinese data from $[12,13]$. Yaoming Ye and Cuiling Ji, Fangzhi Fan and Lijun Zhang, Xiaofeng Hu and Jing Shen make geographical analysis, comparing different regions in China, namely Eastern, Western and Central China [14-16].

\section{Financialization Hampers Industrial Development}

Most of North America and European literatures focus on the negative effects of financialization on growth and industry in the long term, though the American economy was partly boosted by the virtual economy derived from financial innovations, derivatives and corporate buybacks. The derivation can be manifested from three perspectives.

The first perspective is based on investment. The allocation of resources to stock repurchases is at the expense of investments in innovation and job creation [17]. He further explained the problem with the "retain-and-reinvest" allocation regime [17]. Investments in innovation, therefore, require committed finance, or "patient capital". In a company that has already had successful products, the foundation of committed finance is earnings retained out of profits; 
part of past gains from innovation provides committed finance for the next round of innovation. Based on this mechanism, Hwan JooSeo investigates the effects of financialization on research and development (R\&D) investment by nonfinancial corporations in Korea from 1994 to 2009 [18], and suggests that increased dividend payments and stock buybacks impeded R\&D investment by reducing internal funds and planning horizons. Stockhammer finds that financialization "contributed to" a slowdown in investment by non-financial corporations and can thus be blamed for the slowdown in economic growth in those countries since the 1980s [19]. Crotty in a study of firm behavior in the American non-financial corporate sector also finds a negative relation between financialization and investment in machinery and equipment [20]. Yumin Zhao [5] has shown how world financialization exerts pressures on China's manufacture international trading and the international environment running them.

The second perspective is from capital accumulation. Ozgur Orhangazi associates financialization with a rise in the share of national income accruing to the holders of financial assets and a concomitant decline in the share of labor [21], an increase in financial instability, slower growth, and dimmer prospects for economic prosperity, which slowed the rate of capital accumulation. Dumenil and Levy note that the rate of capital accumulation is closely related to the rate of retained profit, that is, the rate of profit after payment of interest and dividends [22]. By forcing an increase in interest and dividend payments, financialization left NFCs (non-financial corporations') with fewer funds and contributed to a slowdown of investment in France and the United States.

A third approach involves studies of financialization and industrial development with the rise of the global value chain. What distinguishes these studies from others is the concern of financialization at a micro level. Financialization is considered mainly as the non-financial firms have increasingly used finance rather than production as both a source and a use of their funds [23]. The off-shoring strategies accepted by non-financial corporations have made it difficult for U.S. leading firms to reduce costs through global value chains, reducing real economic investment as well. Milberg [24] writes in the book Outsourcing Economics:

The traditional business model of retaining profits to finance growth through investment has been giving way to a strategy of focusing on core competence and maximizing shareholder value. The new model has been built on the strategy of lead firm governance of global production networks, aimed at cutting costs and reducing production-side risk. This has permitted the U.S. non-financial corporate sector to behave increasingly like the financial sector, purchasing more financial assets and raising dividends and executive compensation rather than investing in the real economy.

Mubin Zhang extends the framework to industrial structure [25]. He believes that the global value chain characterized by high margin and shareholder value orientation will prompt developing countries from financialization to over-financialization, causing asset price bubbles. International trading works as a linkage to deliver the virtual bubbles from the US into China's highly open sectors, hampering the development in real economy, as well as industrial restructuring.

While the two points of the literature concerning financialization and industrial development are discussed theoretically, this paper examines empirically the relationship between financialization and industrial development in China during the last two decades. 


\section{Empirical Models}

MODEL AND DATA

Since Nelson and Plosser's well-known paper [26], the unit-root property of macro- economic variables has been widely accepted. As such, a unit-root test is often necessary before empirical studies. Based on the result by Dickey and Fuller, the Augmented Dickey and Fuller (ADF) test is generally employed as shown below [27]:

$\Delta y_{t}=\alpha+\beta t+(\rho-1) \mathrm{y}_{t-1}+\sum_{i=1}^{k-1} \theta_{i} \Delta y_{t-i}+a_{t}$

Where $\Delta=1-L ; y_{t}$ is a macroeconomic variable such as exchange rate or stock price; $\mathrm{t}$ is a trend variable; and $a_{t}$ is a white noise term. The null hypothesis is $H_{0}: \rho=1$ and $y_{t}$ is said to possess the unit root property if one fails to reject $H_{0}$.

Nevertheless, the ADF test is suspect when the sample period includes some major events (for example, Great Dpression, oil shocks). Failure to consider it properly can lead to erroneous conclusions in the case when the null is not rejected. To circumvent this problem, Perron and Vogelsang introduce a dummy variable into Eq. (1) and recalculate the new set of critical values [28]. However, Zivot and Andrew pointed out a skeptical observation of the data, and hence problems associated with 'pre-testing' are applicable to his method [29]. Consequently, they introduce an alternative formulation to overcome the pretesting problems.

$$
\Delta y_{t}=\alpha+\beta t+(\rho-1) \mathrm{y}_{t-1}+\gamma D U_{t}(\lambda)+\sum_{i=1}^{k-1} \theta_{i} \Delta y_{t-i}+a_{t}
$$

Where $D U_{t}(\lambda)=1$ for $t>T \lambda$, otherwise $D U_{t}(\lambda)=0 ; \lambda=T_{B} / T$ represents the location where the structural break lies; $\mathrm{T}$ is sample size; and $T_{B}$ is the date when the structural break occurred. Evident from Eq. (2), the estimation result hinges critically on the value $\lambda$ as well.

One of the better ways to test the existence of a unit root is to choose the breakpoint that gives the least favorable result for the null of $H_{0}: \rho=1$ using the test statistics $t_{\hat{\rho}}(\lambda)$. That is, $\lambda$ chosen to minimize the one-sided t statistic for testing $\rho=1$, when small values of the model. To investigate the static assumption of several I (1) variables, the majority of academicians still rely on the widely-accepted and easy-to-apply model proposed by Engle and Granger (1987) despite its normalization problem. Just as the ADF model fails to consider problems associated with structural breaks, the Engle-Granger formulation bypasses the same difficulty. Applying the similar approach by Zivot and Andrews [29], Gregory and Hansen revise the Engle and Granger [30] model to consider the regime shift via residual-based co-integration technique [31]. The Gregory and Hansen model is a two-stage estimation process of which the first step is to estimate the following multiple regressions:

$\mathrm{y}_{1 t}=\alpha+\beta t+\gamma D U_{t}(\lambda)+\theta_{1} y_{2 t}+e_{t}$

In which $\mathrm{y}_{1 t}$ and $y_{2 t}$ are of I (1) and $y_{2 t}$ is a variable or a set of variables; and $D U_{t}(\lambda)$ has the same definition as that in Eq.(2). The second step is to test if $e_{t}$ is found to be consistent with $\mathrm{I}(0)$, one may claim that co-integration exists between $\mathrm{y}_{1 t}$ and $y_{2 t}$. Once the statistical property of $e_{t}$ is established, one may adopt the bivariate VAR model to test the Granger causality. If the co-integration does not exist, the following formulation is needed in testing the hypotheses: 
$\Delta y_{1 t}=\alpha_{0}+\sum_{i=1}^{k} \alpha_{1 i} \Delta y_{1 t-i}+\sum_{i=1}^{k} \alpha_{2 i} \Delta y_{2 t-i}+\varepsilon_{1 t}$
$\Delta y_{2 t}=\beta_{0}+\sum_{i=1}^{k} \beta_{1 i} \Delta y_{1 t-i}+\sum_{i=1}^{k} \beta_{2 i} \Delta y_{2 t-i}+\varepsilon_{2 t}$

In which $y_{1 t}$ and $y_{2 t}$ represent shock prices and exchange rates. Failing to reject the $H_{0}$ : $\alpha_{21}=\alpha_{22}=\cdots \alpha_{2 k}=0$ implies that financialization does not Granger cause industrial development. Likewise, failing to reject the $H_{0}: \beta_{11}=\beta_{12}=\cdots \beta_{1 k}=0$ suggests that financialization does not Granger cause industrial development. If co-integration exists between $y_{1 t}$ and $y_{2 t}$, an error correction term is required in testing Granger causality as shown below:

$$
\begin{aligned}
& \Delta y_{1 t}=\alpha_{0}+\delta_{1}\left(y_{1 t-1}-\gamma y_{2 t-1}\right)+\sum_{i=1}^{k} \alpha_{1 i} \Delta y_{1 t-i}+\sum_{i=1}^{k} \alpha_{2 i} \Delta y_{2 t-i}+\varepsilon_{1 t}(6) \\
& \Delta y_{2 t}=\beta_{0}+\delta_{2}\left(y_{1 t-1}-\gamma y_{2 t-1}\right)+\sum_{i=1}^{k} \beta_{1 i} \Delta y_{1 t-i}+\sum_{i=1}^{k} \beta_{2 i} \Delta y_{2 t-i}+\varepsilon_{2 t}
\end{aligned}
$$

In which $\delta_{1}$ and $\delta_{2}$ denote speeds of adjustment. According to Engle and Granger (1987), the existence of co-integration implies the causality among the set of variables as manifested by $\left|\delta_{1}\right|+\left|\delta_{2}\right|>0$. Failing to reject the $H_{0}: \alpha_{21}=\alpha_{22}=\cdots \alpha_{2 k}=0$ and $\delta_{1}=0$ implies that financialization does not Granger cause industrial development while failing to reject $H_{0}: \beta_{11}=\beta_{12}=\cdots \beta_{1 k}=0$ and $\delta_{2}=0$ indicates financialization does not Granger cause industrial development.

\section{Model Specification}

To show that financialization factors could influence industrial development in the aspect of industrial rationalization, upgrading and stabilization, model (8) is used:

$L N F I R_{t}=\beta_{0}+\beta_{1} L N T L_{t}+\beta_{2} L N T S_{t}+\beta_{3} L N R_{t}+u_{t}(8)$

Where $L N=L o g ; \quad L N F I R=$ financialization factor; LNTL=industrial rationalization; LNTS =industrial upgrading; LNR=industrial stabilization. $u$ =the disturbance term, that is, the stochastic element in the behavior equation, which cannot be observed. $\beta_{0}, \quad \beta_{1}, \quad \beta_{2}, \quad \beta_{3}$ are the parameters.

\section{Financialization Measures}

\section{DATA}

Following the seminal statement of the hypotheses by Bolton P, Goldsmith postulated a positive bivariate relationship between the financial interrelations ratio (FIR) and economic growth; and defined the FIR as follows [32-35]:

$F I R=\left(F_{n}+F_{x}+F_{f}\right) / W$

Where $F_{n}, F_{x}, F_{f}$ denote the market value of domestic non-financial, foreign (net), and financial institutions' instruments outstanding, respectively; $W$ is the market value of national wealth. FIR is the most popular indicator, which in short is the ratio of financial gross asset to GDP. This indicator has been used by Mubin Zhang [25], Lei Feng, Fang Wang [12] among the others. Zexiang Cai worked out an index system to measure financialization, but this index system is not as good as FIR in the sense of operability [36]. 


\section{Industrial Rationalization Measures}

Industrial rationalization is the equitable allocation of resources between different industries. A traditional indicator of financial development is the industrial structure deviation model, referring to an asymmetric degree which can reflect relative discrepancy of every industry on labor productivity. It can be employed for analyzing the employment structure and production value structure, and the corresponding model could be built as:

$$
E=\sum_{i=1}^{n}\left|\frac{Y_{i} / L_{i}}{Y / L}-1\right|=\sum_{i=1}^{n}\left|\frac{Y_{i} / Y}{L_{i} / L}-1\right|
$$

Where $\mathrm{E}=$ structure aviation; $\mathrm{Y}=$ output value; $\mathrm{L}=$ employment; $\mathrm{i}=\mathrm{industry} ; \mathrm{n}=$ total number of industry; $\mathrm{Y} / \mathrm{L}=$ productivity. According to classical economic hypothesis, the productivity of different industries tend to be same at the economic equilibrium level, namely $Y_{i} / \mathrm{L}_{i}=Y / L$, $\mathrm{E}=0$, where $Y_{i} / Y=$ output structure; $L_{i} / L=$ employment structure. The bigger the absolute value of some industry, the more asymmetric the deviation of the industry will be. As the economic asymmetric is a common phenomenon, the value of $\mathrm{E}$ will never be zero, especially in developing countries [37]. However, the structural deviation model assigned the same weight to each industry, ignoring the various importance of different industries. In addition, the absolute value is inconvenient in calculation.

Theil index is another indicator for measuring industrial rationalization. It has the same foundation as the structural deviation model, while overcoming the shortcomings. Specifically, Theil index allocates different weights to industries according to their productivities, and makes use of natural logarithm to avoid using absolute value. Theil index can be built as:

$$
T L=\sum_{i=1}^{n}\left(\frac{Y_{i}}{Y}\right) \ln \left(\frac{Y_{i}}{L_{i}} / \frac{Y}{L}\right)
$$

The variables have the same meaning with the above. If the TL value equals zero, the GDP structure of this industry keeps up with the employment structure, indicating the industrial structure is at the high-point and the industry achieves full employment; and if the value is less than zero, the more the absolute value of minus value, the more serious the invisible unemployment will be, and the bigger the scale of surplus labors is, and the more urgent the labor transfer will be; if the value is more than zero, there is a lack of labors in this industry and the actual labor productivity is higher than those of other industries. The bigger the positive value, the more serious the discrepancy of labors will be, and the more possible for the industry to absorb labors from other industries.

\section{Industrial Upgrading Measures}

Industrial upgrading is defined as the process by which industry actors-sectors, products and workers move from low-value to relatively high-value activities. Industrial upgrading in China is always in the same pattern of industrial structure upgrading, which can be measured by the empirical method. As a developing country, industrial structure upgrading is signed by upgrading of non-agricultural industry, especially the increasing ratio of service sector to manufacture sector. So, in this paper we use the ratio of service sector output value to that of manufacture sector. The bigger the ratio, the more advanced the industrial upgrading. 


\section{Industrial Stability Measures}

Industrial stability is the final goal of industrial development, depicting a state of harmony among different industries and sectors. Many literatures built the stability model from industrial value chain with a micro-view, only Deyun Xu built industrial stability from macroview. According to his derivation, the measurement to industrial stability is [38]:

$$
R=\sqrt{\sum_{i=1}^{3}\left(\frac{y_{i}}{l_{i}}-1\right)^{2} / 3}(R \geq 0)
$$

Where $\mathrm{R}=$ industrial stability level; $\mathrm{i}=$ industry; $y_{i} / l_{i}=$ ratio of labor to income. If the $\mathrm{R}$ value equals to zero, the industry is equalized; the bigger the $\mathrm{R}$ value, the more asymmetric the industries.

Because the data have different units, they should be standardized with following formula:

For positive indexes:

For negative indexed:

$$
c_{i j}^{\prime}=\frac{c_{i j}-\operatorname{minc}_{j}}{\operatorname{maxc}_{j}-\operatorname{minc}_{j}} 0 \leq c_{i j} \leq 1
$$

$$
c_{i j}^{\prime}=\frac{\operatorname{maxc}_{j}-c_{i j}}{\operatorname{maxc}_{j}-\operatorname{minc}_{j}} \quad 0 \leq c_{i j} \leq 1
$$

All the index values are controlled from 0 to 1, with their characters maintained.

Table1. Summary statistics of standardized variables

\begin{tabular}{cccccc}
\hline Standardized variable & Mean & SD & Max & Min & Observations \\
\hline SFIR & 0.436 & 0.288 & 1 & 0 & 34 \\
STL & 0.398 & 0.199 & 1 & 0 & 34 \\
STS & 0.594 & 0.310 & 1 & 0 & 34 \\
SR & 0.359 & 0.216 & 1 & 0 & 34 \\
\hline
\end{tabular}

Source: China Statistical Yearbook (2013); National Bureau of Statistics of the People's Republic of China (http://www.stats.gov.cn); The People's Bank of China (http://www.pbc.gov.cn)

STL refers to standardized industrial rationalization; STS refers to standardized industrial upgrading; SR refers to standardized industrial stability.

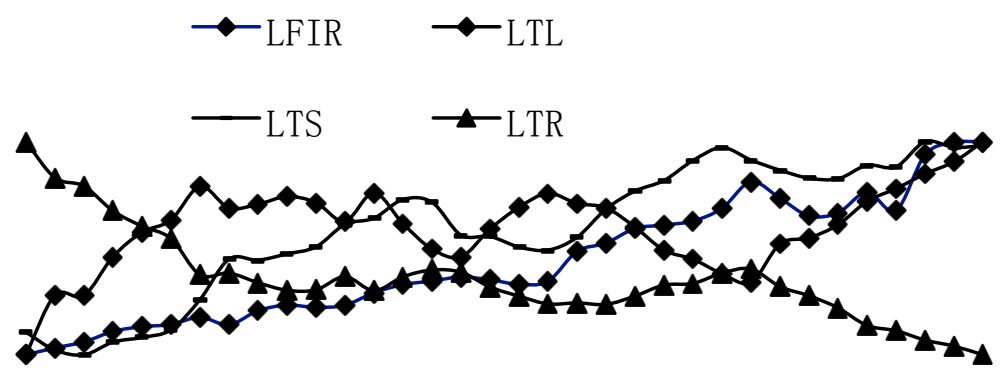

Figure China's financialization and industrial development from 1978-2011

Source: China Statistical Yearbook (2012); National Bureau of Statistics of the People's Republic of China (http://www.stats.gov.cn); The People's Bank of China (http://www.pbc.gov.cn)

In Figure a, we see that from 1978-2011, the process of financialization and industrial development changed a lot in China. Financialization went through a rising route, which also happened in industrial upgrading and stability. However, industrial rationalization undergoes 
a decreasing path. These trends can be explained by China's economic reform and industrial development strategies.

China's reform efforts began in 1978 with the Third Plenum of the $11^{\text {th }}$ National Party Congress, and reforms accelerated after China's 2001 accession to the World Trade Organization (WTO) [39]. Financial sectors have many great chances for development after 1978, so the financial gross capital accumulated, as is shown by FIR. The participation of China into the global economy is characterized by low-cost labor and initial products output. Furthermore, the government aggressively attracts foreign capital which strengthens the international trade as well. As a result, manufacture industry is boosted from initial products to high-tech products, which contribute to industrial rationalization and upgrading; however, industrial stability is hampered in this process.

\section{EMPIRICAL RESULTS}

This section is the analysis of empirical results given by VAR model, including ADF unit root test, cointegration test, Granger causality test and impulse response analysis. We focus on the interactions between financialization and industrial development.

\section{ADF Unit Root Test}

To ascertain the order of integration of the variables in our model, we first applied the augmented Dickey Fuller unit root tests. The null hypothesis of the test is that the series has a unit root. If the null hypothesis is rejected, we can conclude that the series is stationary. The results of these two unit root tests are summarized in Table 2.

Table 2. ADF unit root test

\begin{tabular}{ccccc}
\hline Variable & ADF test & Test equation & Lag length & Significance level (critical value) \\
\hline LNFIR & 3.300 & Without trend and intercept & 0 & $1 \%(-2.637)$ \\
$\triangle$ LNFIR & $-4.861^{* *}$ & Without trend and intercept & 1 & $1 \%(-2.639)$ \\
LNTL & 1.528 & Without trend and intercept & 0 & $1 \%(-2.637)$ \\
$\triangle$ LNTL & $-4.614^{* *}$ & Without trend and intercept & 1 & $1 \%(-2.639)$ \\
LNTS & -2.460 & Without trend and intercept & 0 & $1 \%(-2.637)$ \\
$\triangle$ LNTS & $-3.619^{* *}$ & Without trend and intercept & 1 & $1 \%(-2.639)$ \\
LNR & 2.572 & Without trend and intercept & 0 & $1 \%(-2.637)$ \\
$\triangle$ LNR & $-3.912^{* *}$ & Without trend and intercept & 1 & $1 \%(-2.639)$ \\
\hline
\end{tabular}

Notes: ${ }^{* *}$ represents reject null hypothesis at the significance level of $1 \%$

\section{Cointegration Test}

The time series data of financialization and industrial development share a common stochastic drift at the same finite difference. As a result, we can use Johansen to further test the cointegration relationship among the variables. Before the Johansen test, we are supposed to decide the optimal lag length. 
Table3. Lag selection for cointegration test

\begin{tabular}{cllllc}
\hline \multirow{2}{*}{ Lag length } & \multicolumn{5}{c}{ Without deterministic trend } \\
\cline { 2 - 6 } & LR & FPE & AIC & SC & HQ \\
\hline 2 & $28.021^{*}$ & $1.84 \mathrm{e}-11^{*}$ & $-13.430^{*}$ & -11.781 & -12.884 \\
4 & 23.187 & $1.14 \mathrm{e}-11^{*}$ & $-14.456^{*}$ & -11.280 & $-13.440^{*}$ \\
\hline
\end{tabular}

Notes: * statistical significance at the $1 \%$ levels.

The results of the lag selection criteria in Table 3 suggest that the optimal numbers of lags are 2 and 4. Combined with Q statistic test, White test and JB test, the lag number 4 shows better effect. The results of the cointegration test for the bounds testing approach are reported in Table 4 . The Eigen value fall outside the upper bound and are statistically significant at the 5\% level. Thus, evidence of cointegration among the variables is not rejected. Thus, there is a longrun equilibrium relationship among financialization, industrial rationalization, upgrading and stability.

Table 4 Unrestricted Cointegration Rank Test

\begin{tabular}{ccccc}
\hline Hypothesis & Eigen value & Max-Eigen statistic & Critical Value & Prob \\
\hline None $^{* *}$ & 0.764 & 79.424 & 47.856 & 0 \\
At most 1 & 0.512 & 37.593 & 29.797 & 0.005 \\
At most 2 & 0.438 & 16.789 & 15.495 & 0.032 \\
At most 3 & 0.003 & 0.094 & 3.842 & 0.759 \\
\hline "** & denotes rejection of the hypothesis at the 0.01 level.
\end{tabular}

From Table 3, we can find three cointegrating relations with the data of LNFIR, LNTS, LNTL and LNR. The estimated equation is:

$$
\begin{aligned}
& \text { LNFIR=3.097675LNTL+0.094729LNTS- } \\
& \text { 4.046037LNR } \\
& \text { St. (0.121) (0.116) (0.205) }
\end{aligned}
$$

The cointegrating equation shows : In China, from 1978 to 2012, financialization has positive relationships with industrial rationalization and upgrading. However, a negative relationship is observed between financialization and industrial stability.

\section{Granger causality test}

We use the Granger causality test to find the short period relationship among financialization,

\begin{tabular}{|c|c|c|c|c|}
\hline Variables & Null Hypothesis & Lag length & observations & P Value \\
\hline \multirow{2}{*}{ LNTL } & LNTL does not Granger cause LNFIR & 4 & 32 & 0.2145 \\
\hline & LNFIR does not Granger cause LNTL & 4 & 32 & 0.3818 \\
\hline \multirow{2}{*}{ LNTS } & LNTS does not Granger cause LNFIR & 4 & 32 & 0.2293 \\
\hline & LNFIR does not Granger cause LNTS & 4 & 32 & 0.3570 \\
\hline \multirow{2}{*}{ LNR } & LNR does Granger cause LNFIR & 4 & 32 & 0.0452 \\
\hline & LNFIR does Granger cause LNR & 4 & 32 & 0.0915 \\
\hline
\end{tabular}
industrial rationalization, upgrading and stability.

Table 5 The Results of the Granger Causality test

The results of the Granger causality test results are reported in Table 5. It shows that at the optimal lag number of 4 , financialization and industrial stability are found to have bidirectional 
Granger causality, while the Granger causality doesn't exist among financialization, industrial rationalization and upgrading. Generally, the result of cointegration produces about the same conclusion regarding Granger causality among financialization, industrial rationalization, upgrading and stability.

\section{Impulse response analysis}

From the Granger causality test, we conclude that industrial stability can explain financialization. Furthermore, we resort to impulse-response functions to investigate the dynamic impact between the two variables. The impulse response results are shown in Figure b.
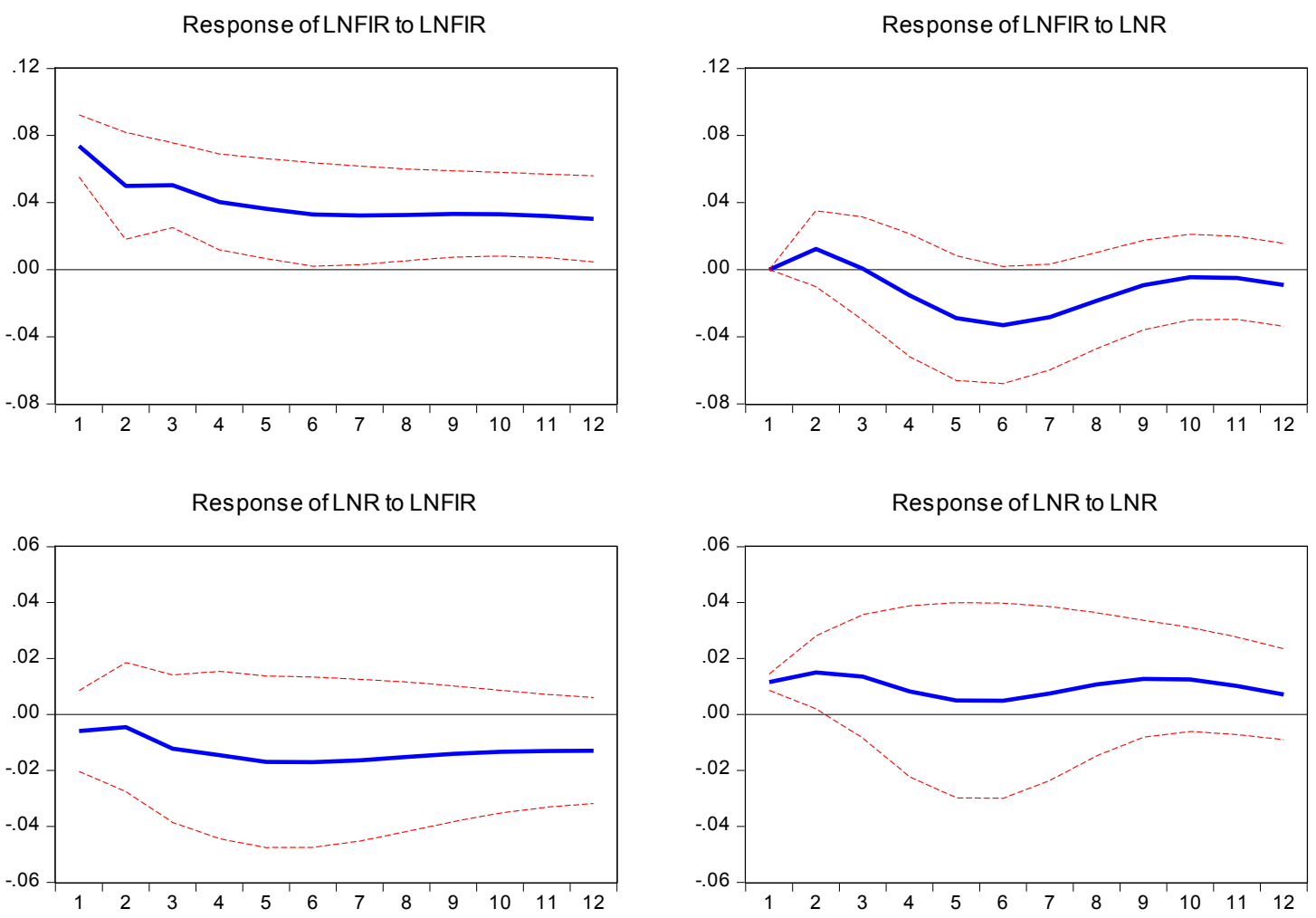

Figure b. Impulse-response function between financialization and industrial stability

We can see from Figure $b$ that a positive financialization shock interrupts the stability of industry, while a positive industrial stability shock improves the level of financialization. Theoretically, the financialization should improve economic stabilization of industry, but this does not appear to be happening according to empirical results. The possible reason is that the existing level of financialization is still low, and resources allocation is not proper, so the promotion function is hard to observe.

\section{CONCLUSIONS}

This paper has examined the relationship between financialization and industrial rationalization, upgrading, stability in China using cointegration, Granger causality and impulse-response testing, with the annual data from 1978-2012. The results of the Granger test show some evidence that financialization and industrial stability are found to have bidirectional Granger causality. In other words, there is a dynamic relationship between financialization and industrial stability. Built on the further research of impulse-response analysis, we find that a positive financialization shock impairs the stability of industry, while a positive industrial stability shock improves the level of financialization. 
Our results suggest that in the long run, a positive relationship exists between financialization and industrial stability. However, the increasing level of financialization causes instability within industries. The results can be explained by the derivatives accompanied with financialization, which attract money from the real economy to the financial field. In other word, the speculative funds are regarded as a factor causing industrial instability. The results from this paper can not only help us have a clear view on the effects of financial development in China, but also have implications to other developing countries in the aspect of financial development and industrial development.

\section{References}

1. Qi, L., the Influence of the Globalization of Monopoly Capital on China's Industrial Development. Social Sciences in China, 2009(2): p. 83-97.

2. Yi, G. and W. Song, The evolution of China's financial asset structure: from 1991 to 2007. 2008.

3. Foster, J.B., The financialization of capitalism. Monthly Review, 2007. 58(11): p. 1-14.

4. Milberg, W., Shifting sources and uses of profits: Sustaining US financialization with global value chains. Economy and Society, 2008. 37(3): p. 420-451.

5. Zhao, Y., The influence of world economic financialization on China's manufacture industry. International Trade, 2008(11): p. 49-53.

6. Yang, J., Trend analysis of economic financialization in China. Technology and Market, 2013(5): p. 329-330.

7. Crotty, J., The neoliberal paradox: the impact of destructive product market competition and 'modern'financial markets on nonfinancial corporation performance in the neoliberal era. Financialization and the world economy, 2005: p. 77-110.

8. Panitch, L. and S. Gindin, The current crisis: a socialist perspective. Studies in Political Economy, 2009. 83.

9. Lapavitsas, C., Theorizing financialization. Work, Employment \& Society, 2011. 25(4): p. 611-626.

10. Fu, J. and X. Wu, the Mechanism Analysis of Finance to Industrial Structure Adjustment. Financial Perspectives Journal, 2005(2): p. 30-34.

11. Yang, L. and J. LI, Financial Structure Transition and Real Economy Structure Upgrading. FInance \& Trade Economics, 2002. 2: p. 9-13.

12. Wang, F., Economic financialization and structural adjustment. Financial Research, 2004(8): p. 120-128.

13. Chen, F., The function of finance in industrial structure adjustment. Financial Research, 1996. 11: p. 23-27.

14. Ye, Y. and C. Ji, Influence of Financial development in Yangtze Delta Urban Agglomeration on industrial structure. Shanghai Finance, 2004(6): p. 10-12.

15. Fan, F. and L. Zhang, The research on China's regional financial structure transformation and industrial structure upgrading. Financial Research, 2004(11): p. 36-48.

16. Hui, X. and J. Shen, Financial development and industrial structure upgrading in Eastnorth China: empirical research and comparison. Journal of Harbin Institute of Technology (Social Sciences Edition), 2006. 8(2): p. 87-91.

17. Lazonick, W., The Chandlerian Corporation and the theory of innovative enterprise. Industrial and Corporate Change, 2010.19(2): p. 317-349.

18. Seo, H.J., H.S. Kim, and Y.C. Kim, Financialization and the Slowdown in Korean Firms' R\&D Investment*. Asian Economic Papers, 2012. 11(3): p. 35-49.

19. Stockhammer, E., Financialisation and the slowdown of accumulation. Cambridge Journal of Economics, 2004. 28(5): p. 719-741.

20. Crotty, J., Structural causes of the global financial crisis: a critical assessment of the 'new financial architecture'. Cambridge Journal of Economics, 2009. 33(4): p. 563-580. 
21. Orhangazi, Ö, Financialization and the US Economy2008: Edward Elgar Publishing.

22. Duménil, G. and D. Lévy, The real and financial components of profitability (United States, 1952-2000). Review of Radical Political Economics, 2004. 36(1): p. 82-110.

http://rrp.sagepub.com/content/36/1/82

23. Millberg, W. and D. Winkler, Financialization and the dynamics of off-shoring in the US. Cambridge Journal of Economics, 2010. 34(2): p. 275-293.

24. Milberg, W. and D. Winkler, Outsourcing economics: global value chains in capitalist development2013: Cambridge University Press.

25.Zhang, M., The Financialization of non-finance sector and Industrial Structure Update in China. Guangming Daily (China), 2010: p. 6-22.

26. Nelson, C.R. and C.R. Plosser, Trends and random walks in macroeconmic time series: some evidence and implications. Journal of monetary economics, 1982. 10(2): p. 139-162.

http://www.sciencedirect.com/science/article/pii/0304393282900125

27. Dickey, D.A. and W.A. Fuller, Distribution of the estimators for autoregressive time series with a unit root. Journal of the American statistical association, 1979. 74(366a): p. 427-431.

28. Perron, P. and T.J. Vogelsang, Testing for a unit root in a time series with a changing mean: corrections and extensions. Journal of Business \& Economic Statistics, 1992. 10(4): p. 467-470.

29.Zivot, E. and D.W.K. Andrews, Further evidence on the great crash, the oil-price shock, and the unit-root hypothesis. Journal of Business \& Economic Statistics, 2002. 20(1): p. 25-44.

30. Engle, R.F. and C.W. Granger, Co-integration and error correction: representation, estimation, and testing. Econometrica: journal of the Econometric Society, 1987: p. 251-276.

31. Gregory, A.W. and B.E. Hansen, PRACTITIONERS CORNER: Tests for Cointegration in Models with Regime and Trend Shifts. Oxford bulletin of Economics and Statistics, 1996. 58(3): p. 555-560.

32. Goldsmith, R.W., the Financial Development of India, Japan, and the United States: A Trilateral Institutional, Statistical, and Analytic Comparison1983: Yale University Press.

33. Goldsmith, R.W., the Historical Background: Financial Institutions as Investors in Corporate Stock Before 1952, in Institutional Investors and Corporate Stock--A Background Study1973, UMI. p. 34-90.

34. Goldsmith, R.W., Financial structure and development. Vol. 1. 1969: Yale university press New Haven.

35. Bolton, P., G. Roland, and E. Spolaore, Economic theories of the break-up and integration of nations. European Economic Review, 1996. 40(3): p. 697-705.

36. Cai, Z., J. Wang, and F. Yang, Index System Analysis of China's Financialization. Journal of Nanjing Audit University, 2004(1): p. 49-54.

37. Syrquin, M. and H. Chenery, Three decades of industrialization. The World Bank Economic Review, 1989. 3(2): p. 145-181.

38.Xu, D., the Determination and Measurement of Industry Structure Equilibrium: Study from a New Perspective. Industry Economic Research, 2011(3): p. 56-63.

39. Branstetter, L. and N. Lardy, China's embrace of globalization, 2006, National Bureau of Economic Research. 